\title{
Coastal Communities WTA Compensation for conservation of mangrove forests: a choice experiment approach
}

\author{
Z. Mashayekhi, A. Danehkar ${ }^{\star}$, G.A. Sharzehi and V. Majed \\ University of Tehran, Karaj, Islamic Republic of Iran
}

Received October 31, 2015 - Revised February 9, 2016 - Accepted February 9, 2016

\begin{abstract}
Protection of mangrove forests entails the decrease and restriction of their injudicious uses by local people and therefore imposes opportunity costs on poor local communities, which often depend on these forest resources for their subsistence. This study aims to quantify the economic opportunity cost of conservation for coastal communities living in areas adjacent to mangrove forests in the southern coasts of Iran. The main commercial uses of the mangrove forests in this area are restricted to fishing, tourist boating trips, and limited leaves cutting. We applied a choice experiment method to measure the costs of the forest exploitation reduction under hypothetical protection scenarios in which local users would receive monetary compensation to lessen or forgo mangrove forest utilization. The results showed that local communities are willing to accept lower compensation when the protection is meant to decrease the frequency of Hara cutting and fishing, as opposed to banning recreational opportunities. The mean WTA was estimated to be 55662500 IRR.hsld ${ }^{-1} \cdot \mathrm{yr}^{-1}$ (2026 USD), which was generally lower than opportunity costs in the form of foregone income. Before implementing any policies related to equity, our findings can provide policymakers with useful prior knowledge and prescription.
\end{abstract}

Key-words: Compensation / willingness to accept / hara cutting / fishing / recreational opportunities

\begin{abstract}
Résumé - Volonté de communautés côtières à accepter une compensation pour la conservation de forêts de mangrove : une méthode d'expérimentation des choix. La protection des forêts de mangroves entraîne la diminution et la restriction de leurs utilisations excessives par les populations locales et impose donc des coûts d'opportunité sur les communautés locales pauvres, qui dépendent souvent de ces ressources forestières pour leur subsistance. Cette étude vise à quantifier le coût d'opportunité économique de la conservation pour les communautés côtières qui vivent dans les zones adjacentes aux forêts de mangroves dans les côtes du sud de l'Iran. Les principales utilisations commerciales des forêts de mangroves dans cette région sont limitées à la pêche, aux voyages en bateau de tourisme, et à la coupe de feuilles réglementée. Nous avons appliqué une méthode d'expérimentation des choix pour mesurer les coûts de la réduction de l'exploitation forestière dans des scénarios hypothétiques de protection dans lesquels les utilisateurs locaux recevraient une compensation monétaire pour réduire ou renoncer à l'utilisation de la forêt de mangrove. Les résultats ont montré que les communautés locales sont prêtes à accepter une compensation inférieure lorsque la protection est destinée à diminuer la fréquence de la coupe du Hara et la pêche, par opposition à l'interdiction de possibilités de loisirs. La WTA moyenne a été estimée à 55.662.500 IRR.hsld ${ }^{-1} \cdot \mathrm{yr}^{-1}$ (2026 USD), ce qui était généralement plus bas que les coûts d'opportunité sous forme de manque à gagner. Avant la mise en ouvre des politiques relatives à l'équité, nos résultats peuvent fournir aux décideurs des connaissances préalables utiles et de la prescription.
\end{abstract}

Mots-clés : Compensation / volonté d'accepter / coupe du Hara / pêche / possibilités de loisirs

\section{Introduction}

In recent years, in both research and policy communities, there has been increasing interest in the economic valuation of natural ecosystems and their associated goods and services (Braat and de Groot, 2012; Costanza et al., 2014). In fact, because these natural assets do not trade in ordinary markets, often, they are neglected or even ignored in policymaking and priority-setting practices, leading to degradation or depletion of resources. This gradually undermines the functioning and resilience of ecosystems, thus threatening their ability to continuously supply a flow of services for present and future generations. Economic valuation of ecosystem services is an important tool to enhance public awareness, and it can help policymakers decide how to allocate resources between competing uses (de Groot et al., 2012).

\footnotetext{
^ Corresponding author: danehkar@ut.ac.ir
} 
Mangrove forests are among the most productive and biologically important ecosystems of the world, as they provide unique ecosystem goods and services to human society. They play an important role in stabilizing shorelines in coastal areas and estuaries, protecting them against sea level rise, hurricanes, and coastal erosion (Lee et al., 2014). The mangroves are also considered to be sources of high-value commercial products and fishery resources, as well as sites for burgeoning ecotourism industry (Barbier et al., 2011; Vo et al., 2012; Mitsch and Gosselink, 2015). In addition to providing breeding and nursing grounds for marine and pelagic species, they provide food, medicine, fuel and building materials for local communities (Giri et al., 2010). These services are essential to human well-being and poverty alleviation (MA, 2005).

Much of the world's mangrove forests are located in underdeveloped countries (Christie et al., 2012), where coastal communities are mainly characterized by relative geographic isolation, chronic poverty, and significant traditional dependence on the harvest of mangrove resources for their subsistence and livelihood (Walters et al., 2008). Mangroves are exhibiting the highest rapid loss rates of ecosystems worldwide (Valiela et al., 2001). Since 1980, due to population pressure in coastal areas and changes in land use, more than $20 \%$ of the world's mangrove forests, which is a total of 3.6 million hectares, has been destroyed (FAO, 2007).

In this regard, there is an urgent need to avoid irreversible losses and further degradation of remaining mangrove forests by developing efficient monitoring and conservation plans. Conservation of mangrove forests would likely require adopting restrictions on household use of forest resources (Bush et al., 2011), and therefore imposes opportunity costs on poor local communities that currently use these forests to maintain their livelihoods. These opportunity costs should be properly identified and the adequate incentive-based mechanisms for integrating local people into forest conservation programs applied by relevant administrators. However, Communities are not homogeneous and there is a degree of variation in the costs of forest use restrictions across households (Bush et al., 2011).

A key entry point to understanding the real socio-economic impacts of forest management and conservation programs, under conditions of local subsistence use, is assessing the minimum compensation necessary to incentivize forest conservation (Bush et al., 2011). One possible avenue to capture and evaluate the true willingness-to-accept (WTA) compensation is to use stated preference methods (Bakkegaard et al., 2012). Despite a growing application of stated preference studies addressing WTA payments in the form of CV (de Groot and Hermans, 2009; Gadaud and Rambonilaza, 2010; Bakkegaard et al., 2012; Bush et al., 2013), studies attempting to assess the WTA in the form of CE are highly uncommon, with Casey et al. (2008) being one exception.

In a choice experiment (CE), individuals are given a hypothetical setting and asked to choose their preferred option among several alternatives in a choice set, and they are usually asked to perform a series of such choices. Each alternative is described by a number of attributes or characteristics. When describing the profile of the presented alternative, a monetary value is included, along with other important attributes (Alpizar et al., 2003). Inclusion of a cost attribute makes it possible to obtain indirectly the respondent's willingness to pay (WTP) or willingness to accept (WTA) either for the good in its entirety, or the respondent's WTP/WTA for the attribute, i.e., marginal WTP/WTA (also termed part worth or implicit price) (Bennett and Blamey, 2001).

The first study to apply choice experiments to non-market valuation of environmental resources was by Adamowicz et al., 1994, followed by an increasing number of studies (see Boxall et al., 1996; Carlsson et al., 2003; Birol and Cox, 2007; Liu and Wirtz, 2010; Jobstvogt et al., 2014). The application of $\mathrm{CE}$ for environmental policy and planning is relatively recent and of growing interest in developing countries (e.g., Kaffashi et al., 2012; Jalili and Sharzehi, 2013).

The focus of this study is to quantify the economic opportunity costs of conservation for communities living in areas adjacent to the mangrove forests in the southern coasts of Iran. Using the CE approach, we assessed the WTA compensation among rural households in Hara Biosphere Reserve (HBR) for reducing tree harvesting and deforestation activities on their lands. We designed some hypothetical scenarios in which local users would receive monetary compensation to lessen or forgo mangrove forest utilization. Hara forest is the common name for mangrove forests in the southern coasts of Iran, dominated by the Avicennia marina species. Recently, the destructive effects of industrialization and development, as well as global environmental changes, have been threatening the status of the Hara forest ecosystems (Zahed et al., 2010). Although the extent of Hara forests in Iran has not changed significantly over the last decades, the quality of the stands has severely deteriorated, due primarily to camel grazing of mangrove leaves, unscheduled recreational activities, oil pollution due to fuel smuggling, introduction of an invasive species (black rat) and unregulated fishing.

\section{Field-site description}

The study was conducted in the Hara Biosphere Reserve (HBR) area at the mouth of the Hormuz strait, between Qeshm Island and the southern coasts of Iran. With an area of approximately $85686 \mathrm{ha}$, the region contains the largest stand of Iranian mangrove forests (Iran's National Document of Mangrove forests, 2013). Much of the area is taken up by the Mehran delta, which forms extensive Intertidal flats, and has a marshy coastline and vast mangrove formation. Figure 1 illustrates the location map of the area. The dominant climate is subtropical, with extremely high summer temperatures that exceed $40{ }^{\circ} \mathrm{C}$. Rainfall is low, with an annual total of 100-300 mm, mainly falling from November to April.

HBR is now managed as a protected area under the authority of the Department of Environment (DOE) of Iran. The Hara protected area was established in 1973 to protect the most extensive stands of natural mangrove forest in the south coast of Iran. It was designated as a wetland of international importance under the Ramsar convention in June 1975. The protected area was additionally designated as a UNESCO (MAB) Biosphere Reserve in June 1976 and was identified as an "important bird area" by Birdlife International in 1994.

HBR is of major importance in its support of breeding, wintering and passing migrant water birds. More 


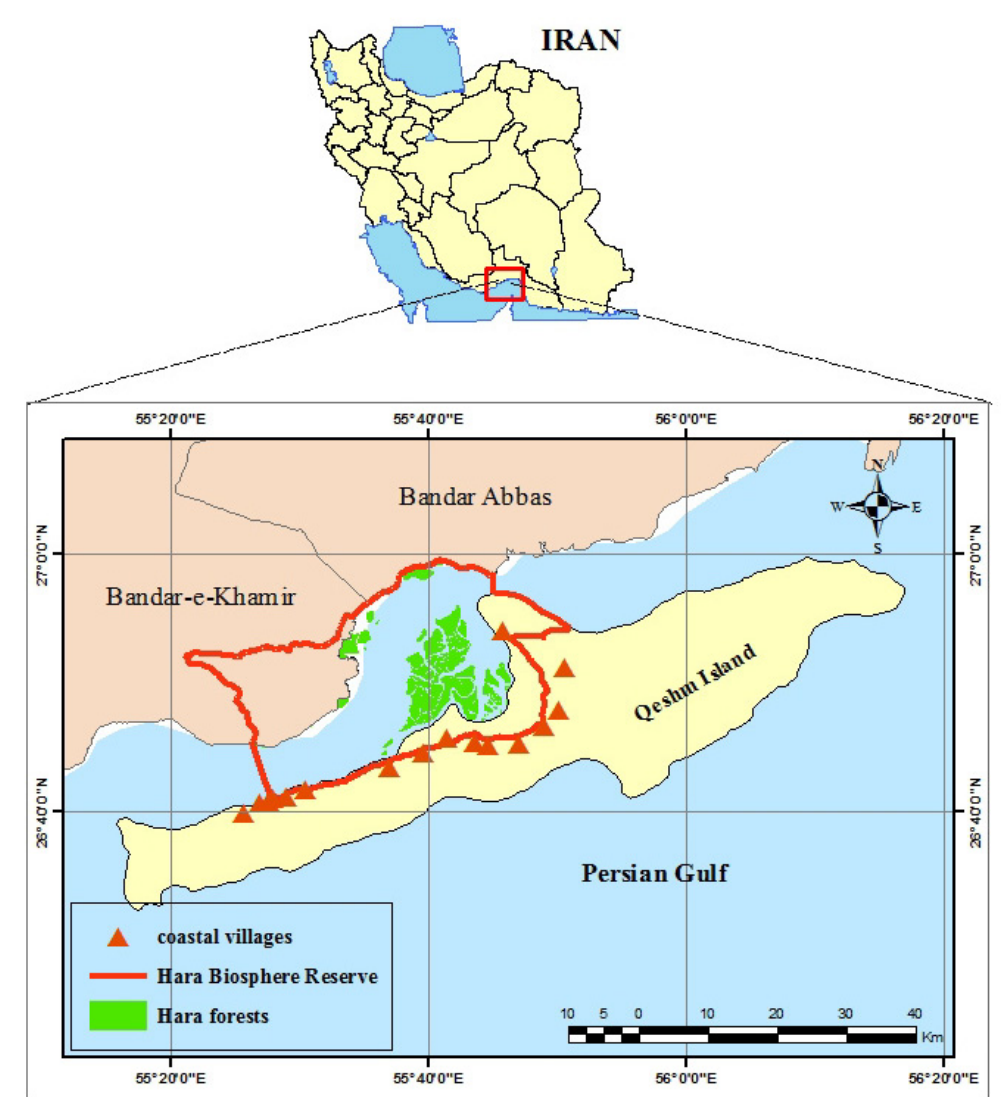

Fig. 1. Study area, Hara Biosphere Reserve (HBR) in southern coasts of Iran.

than 100 species of sea and shoreline birds, 32 species of Persian Gulf and Oman Sea fish, six species of prawn, 10 species of crabs, five species of sea snake, two species of sea turtle and one type of marine mammal have been recognized in the HBR (Neinavaz et al., 2011). The nearest and most important urban center to the HBR is Bandar-e-Khamir. Several coastal villages also lie adjacent to these forests, with a total residential population of approximately 21723 inhabitants in 2014, and are settlements that depend upon Hara forests for their livelihood (Iran's National Document of mangrove forests, 2013). These villagers are mainly a low-income community, and their chief livelihood is small-scale fishing and tourist boat trips. They usually make boat trips to forests to collect Hara leaves and branches, meeting daily needs of the livestock and sometimes trading to farther villages every $2-3$ days. For rehabilitation purposes, some mangrove reforestation was undertaken by the local community involvement in the early 1990s.

\section{Methods}

\subsection{Developing the choice attributes}

The first step in CE question design is to choose a set of attributes related to the study site problem. Based on a literature review (Alongi, 2008; Barbier et al., 2011; O'Garra, 2012), a list of mangrove forest ecosystem services was used to assign potential attributes for the CE design. Then, the attributes were refined through consultation with focus groups and face to face exploratory interviews with experts, officials, managers and local key-informants. Based on the information gathered through the focus group interviews, we finally selected four attributes for this study (Table 1). The payment vehicle was assumed to be a hypothetical monetary compensation that local users would receive for lessening or forgoing Hara forest utilization. The levels of each attribute are also listed in Table 1. To make the model convergence more feasible, the compensation payment levels are divided by 10000 .

\subsection{Designing the hypothetical ce scenarios}

The hypothetical scenarios were built around the government's protection project, planning to maintain the current condition of these forests in the future. Details on how this project will be implemented in the future, or to what extent, were not specified by the time of the survey design. Because protection of Hara forests entails lowering the injudicious uses by local people, the CE's protection scenarios proposed decreasing the current exploitation of Hara forests, in the form of reduced fishing and cutting of Hara, as well as a ban on tourist boat trips. On the other hand, the government promises to compensate local communities for their cost burden.

\subsection{Designing choice tasks}

The experimental design of the choice model survey combined the different attributes and their levels in different combinations. A total of 32 choice sets in four versions were 
Z. Mashayekhi et al.: Knowl. Manag. Aquat. Ecosyst. (2016) 417, 20

Table 1. Attributes and their levels used in choice experiment, Status quo (sq) levels are the highest levels and bold.

\begin{tabular}{|c|c|c|}
\hline Attribute & Description given to the respondents & Attribute levels \\
\hline Recreational opportunities & $\begin{array}{l}\text { Possibility of taking tourists for Hara } \\
\text { forest visiting by boat }\end{array}$ & $\begin{array}{l}\text { you can go with boat to take tourist there } \\
\text { you cannot go with boat to take tourist there }\end{array}$ \\
\hline Cutting Hara & $\begin{array}{l}\text { The average of Hara bundle you cut for feeding } \\
\text { your livestock per marine trip }\end{array}$ & $\begin{array}{l}\text { collecting } 10 \text { bundles Hara.trip } \\
\text { collecting } 5 \text { bundles Hara.trip } \\
\text { collecting } 3 \text { bundles Hara.trip }^{-1}\end{array}$ \\
\hline Fishing & The average amount of fish you catch per day & $\begin{array}{l}\text { catching } 15 \text { kg fish.day } \\
\text { catching } 5-15 \mathrm{~kg} \text { fish.day } \\
\text { catching less than } 5 \mathrm{~kg} \text { fish.day }^{-1}\end{array}$ \\
\hline Compensation payment & $\begin{array}{l}\text { The amount of money you receive as a } \\
\text { compensation per day (in ten thousand Rials*) }\end{array}$ & $\begin{array}{c}\mathbf{0} \\
15 \\
20 \\
25 \\
30 \\
35\end{array}$ \\
\hline
\end{tabular}

${ }^{*}$ Iranin Rial $($ IRR $)=3.64$ E-05 United States Dollar (USD).

\begin{tabular}{|c|c|c|c|}
\hline & Option 1 & Option 2 & option 3 (sq) \\
\hline \multirow[t]{2}{*}{$\begin{array}{l}\text { Recreational } \\
\text { opportunities }\end{array}$} & & & \\
\hline & possible & impossible & possible \\
\hline \multirow[t]{2}{*}{ Cutting Hara } & & & \\
\hline & 5 bunch & 3 bunch & 10 bunch \\
\hline fishery & Less than $5 \mathrm{Kg}$ & $15 \mathrm{Kg}$ & $15 \mathrm{Kg}$ \\
\hline \multirow{2}{*}{$\begin{array}{c}\text { Compensation } \\
\text { payment }\end{array}$} & & 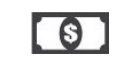 & - \\
\hline & 30 & 15 & 0 \\
\hline Your choice & & & \\
\hline
\end{tabular}

Fig. 2. Sample choice set.

produced using Ngene (econometric software version 1.1.0), where attribute levels were allocated to alternatives according to a D-optimal fractional factorial design that identified all main effects and two-way interactions. Each choice task consisted of two alternatives and one status Quo option. A sample of choice sets is shown in (Figure 2).

\subsection{Developing questionnaires}

In the questionnaires, questions were grouped into three major sections: introduction of the research, choice sets, and socio-economic information. The introductory section was used to initiate contact with respondents, providing respondents with basic information, including the aim of the survey and what was expected of them. Subsequently, they were introduced to the assumed policies and forest protection project.
In the second section (valuation), respondents were asked to make a set of choices. The final section elicited responses to a set of socio-demographic questions. This section included questions about age, gender, occupation, education level, family size, income level, marital status and pro-environment activism. Each questionnaire included one version of the four choice sets with eight different choice sets.

\subsection{Main survey}

To test the questionnaire and clarify the questions, a pilot survey with 40 participants was conducted before the main survey. Based on feedback from participants, several modifications were made to the draft questionnaire. For the main survey, the sample was randomly selected from one coastal town, Bandar-e-Khamir in the northern margin, and 9 villages in the 
southern border of the Hara forests, including Haft Rangoo, Tabl, Melki, Dorbani, Goran, Soheili, Dehkhoda, Kovarzin and Laft. During October-November 2014, a total of 800 questionnaires were filled out using a face-to-face interview method. In principle, every adult household member was allowed to fill out the questionnaire. Data were analyzed statistically using STATA (version 12.1).

\subsection{The econometric model}

$\mathrm{CE}$ has its theoretical foundation in random utility theory and relies on the assumptions of economic rationality and utility maximization (Hall et al., 2004). The random utility approach, developed by McFadden, 1974, is used to link the deterministic model with a statistical model of human behavior. Moreover, Choice experiments were inspired by the Lancastrian microeconomic approach (Lancaster, 1966) in which individuals derive utility from the characteristics of the goods rather than directly from the goods themselves. Under the assumption that the error terms of the utility function are independently and identically distributed (IID) following a type I extreme value (Gumbel) distribution, the choice model can be estimated using a multinomial logit (MNL) specification (McFadden, 1974).

For individual $i$ and alternative $j$, we suppose that utility $U_{i j}$ is the sum of a deterministic (explainable) component, $V_{i j}$, which is typically specified as a linear index of the attributes $(X)$ of the $j$ different alternatives in the choice set, and an unobserved random component $\varepsilon_{i j}$ :

$$
U_{i j}=V_{i j}\left(X_{i j}\right)+\varepsilon_{i j}
$$

We observe the outcome $Y_{i}=j$ if alternative $j$ has the highest utility of the alternatives. It follows that:

$$
\begin{aligned}
\operatorname{Pr}\left(y_{i}=j\right) & =\operatorname{Pr}\left(U_{i j} \geqslant U_{i k}\right), \text { for all } k \\
& =\operatorname{Pr}\left(U_{i k}-U_{i j} \leqslant 0\right), \text { all } k \\
& =\operatorname{Pr}\left(\varepsilon_{i k}-\varepsilon_{i j} \leqslant V_{i j}-V_{i k}\right), \text { all } k
\end{aligned}
$$

Standard multinomial models specify that:

$$
V_{i j}=\dot{X}_{i j} \beta+\dot{Z}_{i} \gamma_{j}
$$

where $X_{i}$ is a vector of choice attributes and $Z_{i}$ are socioeconomic variables.

The probability of a choice $j$ from a choice set consisting of $p$ choices has a closed form depending on the matrix of formalized utilities.

$$
\operatorname{Pr}\{j \text { is selected }\}=\frac{\exp \left(V_{i j}\right)}{\sum_{k=1}^{p} \exp \left(V_{i k}\right)} .
$$

This model can be estimated by conventional maximum likelihood procedures, with the respective log-likelihood function stated in equation (5) below, where $y_{i j}$ is an indicator variable which takes a value of one if respondent $i$ chose option $j$ and zero otherwise.

$$
\log L=\sum_{i=1}^{N} \sum_{j=1}^{L} y_{i j} \log \left[\frac{\exp \left(V_{i j}\right)}{\sum_{i=1}^{J} \exp \left(V_{i j}\right)}\right] .
$$

Once the parameter estimates have been obtained, the implicit price can be derived for each attribute using the formula given by (6) below. The implicit prices express the marginal WTA (mWTA) for a discrete change in an attribute level (i.e., the marginal rate of substitution (MRS) between cost change and the attribute in question) and thus allow some understanding of the relative importance that respondents give to attributes within the design (Bennett and Blamey, 2001):

$$
m W T A=-\frac{\beta_{k}}{\beta_{\mu}}
$$

where $\beta_{k}$ is the coefficient of attribute $k$ and $\beta_{\mu}$ is the coefficient of the monetary attribute. Finally, compensating surplus welfare measures can be obtained for different environmental policy scenarios associated with multiple changes in attributes, using (7), where $V_{0}$ represents the utility of the initial state and $V_{1}$ represents the utility evaluated under changed conditions.

$$
C S=\frac{-1}{\beta_{\mu}}\left(V_{0}-V_{1}\right) \text {. }
$$

\section{Result}

\subsection{Sample characteristics}

The socio-economic characteristics of survey participants shows that the average age of participants was 40.17 years, the majority of respondents were married, the mean household size was 6.27 members, the average household income was 8000000 IRR (290 USD) and 70\% of participants were fisherman (Table 2).

\subsection{Results of the choice experiment}

The conditional logit (CL) model was used to estimate the attribute coefficients. All variables used in the model were dummy variables, apart from the $\mathrm{CP}$, age, hhn, and edu, which were treated as continuous variables (see Table 3 ). We tested for IIA assumption of the CL model using a HausmanMcfadden test (1984), which indicated that the restrictive assumption is not violated in a basic CL framework.

The results of the CL estimation shows that in the simple model (with attributes only), all of main attributes showed a priori expected coefficient signs with $\mathrm{RO}, \mathrm{HC} 2, \mathrm{HC} 3, \mathrm{FSH} 2$ and FSH3 being negative and the $\mathrm{CP}$ attribute being positive; also, all main attributes were significantly different (at the $1 \%$ level) from the baseline across all data sets and estimated models (Table 4). The overall model is significant at the $1 \%$ level, as shown by the chi-square statistic.

Because the first level of each attribute is the highest level or status Quo, the negative signs of RO, HC2, HC3, FSH2 and FSH3's coefficients imply that decreasing the allowable level of Hara forest utilization (due to more protection) brings respondents less utility than would the status Quo, as a priori expected. For CP, the positive coefficient of 0.07 means that as the compensation payment amount increases, respondents are more likely to contribute to protection projects because of 
Table 2. Respondents' socio-economic profile.

\begin{tabular}{|l|c|c|c|c|}
\hline \multirow{2}{*}{ Variable } & \multicolumn{2}{|c|}{ Frequency } & \multirow{2}{*}{ Mean } & Standard deviation \\
\cline { 2 - 3 } Age (years) & Number & $\%$ & & \\
Matrimony status & & & 40.17 & 12.36 \\
Single & 192 & 8 & & \\
Married & 2208 & 92 & & \\
Number in household & & & 6.27 & \\
Education level & & & 6.16 & \\
Illiterate & 288 & 12 & & \\
Elementary school & 1008 & 42 & & \\
Secondary school & 528 & 22 & & \\
High school & 504 & 21 & & \\
College & 72 & 3 & & \\
Job & 1680 & 70 & & \\
Fishermen & 720 & 30 & & \\
Non-fishermen & & & 290 & \\
Monthly Income (USD) & 408 & 17 & & \\
0-185 & 1512 & 63 & & \\
185-330 & 480 & 20 & & \\
330-545 & & & & \\
Involvement in protection projects & 912 & 38 & & \\
Yes & 1488 & 62 & & \\
No & & & \\
\hline
\end{tabular}

Table 3. Attribute variables and levels used in CE.

\begin{tabular}{|c|c|}
\hline Variables & Description \\
\hline RO & $\begin{array}{l}\text { Recreational opportunities (Dummy variable set equals } 0 \text { if respondent allowed to take tourists for Hara } \\
\text { visiting by boat; } 1 \text { : if not) }\end{array}$ \\
\hline $\mathrm{HC} 2 \& \mathrm{HC} 3$ & $\begin{array}{l}\text { Category variable represents the Hara cutting by households; } 1: 10 \text { bundle.trip }^{-1} \text { (baseline); } 2: 5 \\
\text { bundle.trip }^{-1}(\mathrm{HC} 2) ; 3: 3 \text { bundle.trip }^{-1} \text { (HC3) }\end{array}$ \\
\hline FSH2 \& FSH3 & 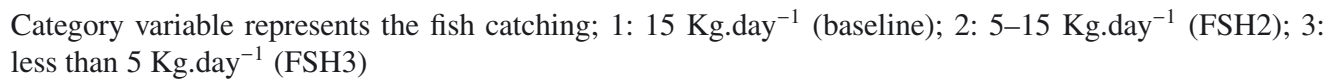 \\
\hline $\mathbf{C P}$ & Compensation payment $(0,15,20,25,30,35$ ten thousand Rials $)$ \\
\hline Age & Age number (range 19 to 71 ) \\
\hline Mat & Matrimony status (1:married; 2 : single) \\
\hline Hhn & Household number (range 1 to 13 ) \\
\hline Edu & Completed education years (range 0 to 16 years) \\
\hline Job & Kind of job (1: fisherman, 0 : otherwise) \\
\hline Inc & Monthly average labor income (6 categories range 300 to 1500 ten thousand Rials) \\
\hline Inv & Involvement in current and previous environmental programs $(1=$ yes; $0=$ no $)$ \\
\hline
\end{tabular}

a perceived increase in utility level. At present, local people do not have the option of receiving compensation payment for reducing their harvests and introducing this option may therefore lead to greater interest in and acceptance of conservation scenarios.

Because social and economic characteristics are constant across choice occasions for any respondents, these can only be considered as interaction terms with experiment attributes. As suggested by McConnel and Tseng (2000), the inclusion of socio-economic attributes is an important step for estimating more accurate models of choice. The interaction variables are composed of 9 socio-demographic factors that are interacting with levels of each main attribute shown in Table 4. Variables $\mathrm{RO}$ and $\mathrm{FSH} 2$ are significant at the $5 \%$ and $10 \%$ level, respectively, with expected negative signs. Other variables are significant (at the 1\% level and less) and have expected coefficient signs.

The interactions between income and recreational opportunities (RO), household number and level 2 Hara cutting, age and level 3 Hara cutting, job and fishing (both levels) and 
Table 4. Estimation results of conditional logit model.

\begin{tabular}{|c|c|c|c|c|c|}
\hline \multicolumn{3}{|c|}{ Simple model } & \multicolumn{3}{|c|}{ Interaction model } \\
\hline Variable & Coefficient & Std. error & Variable & Coefficient & Std. error \\
\hline RO & $-1.7^{* * *}$ & 0.13 & $\mathrm{RO}$ & $-0.91^{\text {** }}$ & 0.38 \\
\hline HC2 & $-0.75^{* * *}$ & 0.15 & $\mathrm{HC} 2$ & $-1.7^{* * *}$ & 0.3 \\
\hline HC3 & $-0.84^{* * *}$ & 0.16 & $\mathrm{HC} 3$ & $-2.46^{* * *}$ & 0.66 \\
\hline FSH2 & $-0.89^{* * *}$ & 0.15 & FSH2 & $-0.86^{*}$ & 0.5 \\
\hline FSH3 & $-1.33^{* * *}$ & 0.16 & FSH3 & $-0.74^{* * *}$ & 0.24 \\
\hline \multirow[t]{10}{*}{$\mathbf{C P}$} & $0.07^{* * *}$ & 0.006 & $\mathrm{CP}$ & $0.78^{* * *}$ & 0.006 \\
\hline & & & RO-inc & $-0.26^{* * *}$ & 0.1 \\
\hline & & & HC2-hhn & $0.14^{* * *}$ & 0.04 \\
\hline & & & HC3-age & $0.06^{* * *}$ & 0.01 \\
\hline & & & HC3-job & $-0.92^{* * *}$ & 0.28 \\
\hline & & & HC3-inc & $-0.18^{*}$ & 0.1 \\
\hline & & & HC3-inv & $0.85^{* * *}$ & 0.25 \\
\hline & & & FSH2-age & 0.02 & 0.01 \\
\hline & & & FSH2-job & $-1.11^{* * *}$ & 0.34 \\
\hline & & & FSH3-job & $-1.03^{* * *}$ & 0.27 \\
\hline AIC & & 1424.6 & AIC & & 1338.6 \\
\hline Max LL & & -706.3 & Max LL & & -654.3 \\
\hline pseudo $R^{2}$ & & 0.19 & pseudo $R^{2}$ & & 0.25 \\
\hline \multicolumn{3}{|c|}{$\chi^{2}(6)=345.19$ (significant at 0.0000 level $)$} & \multicolumn{3}{|c|}{$\chi^{2}(15)=449.16($ significant at 0.0000 level $)$} \\
\hline$N$ & & 2400 & $N$ & & 2400 \\
\hline
\end{tabular}

Notes: statistically Significant at ${ }^{* * *} 1 \%,{ }^{* *} 5 \%$, and ${ }^{*} 10 \%$ level.

level 3 of Hara cutting, involvement in environmental projects and level 3 of Hara cutting are significant. The interaction between income and level 3 Hara cutting is significant at the level $5 \%$, and the interaction between age and level 2 of fishing is insignificant.

The signs of the variables are consistent with our expectation. The positive sign of HC2-hhn, HC3-age and HC3-inv means that older participants, those with larger family size and who have been involved in environmental projects would be expected to choose one of the further protection options relative to the probability of status Quo. On the other hand, these respondents would require additional compensation for having chosen to decrease their utilizations. The negative sign of the interaction between RO-inc and HC3-inc indicates that respondents with higher income prefer status Quo and do not intend to accept money for lessening their exploitation. The negative sign of the interaction between job and level 3 of Hara cutting, as well as job and fishing (both levels), implies that fishermen were less likely to choose one of the protection options.

The overall model is significant at the $1 \%$ level, and the explanatory of the model is high. To some extent, the interaction model fits the data better than the simple model (compare the AIC and pseudo $R^{2}$ values). Accordingly, in the interaction model, the log likelihood ratio decreased from -706.3 to -654.3 and the adjusted $R^{2}$ increased from 0.19 to 0.25 , implying the interaction model is an extremely good fit.

\subsection{Marginal willingness to accept (mWTA)}

The willingness to accept a change in one of the attributes in the choice sets can be found with implicit prices. The
Table 5. Marginal willingness to accept per households.

\begin{tabular}{|l|l|l|l|}
\hline Variable & WTA $\left(\right.$ IRR.day $\left.^{-1}\right)$ & Std. error & 95\% conf. interval \\
\hline RO & 234375 & 1.84 & 198377 to 270372 \\
HC2 & 103924 & 1.81 & 68345 to 139503 \\
HC3 & 116602 & 1.75 & 82250 to 150954 \\
FSH2 & 123260 & 1.99 & 150416 to 162343 \\
FSH3 & 184400 & 1.73 & 150415 to 218381 \\
\hline
\end{tabular}

Note: All parameter estimates significant at $\mathrm{p}=0.001$ level.

marginal WTA for the attributes, calculated based on parameter estimates from Table 4, show that the option of recreational opportunities has the largest WTA (Table 5), with approx. 234000 IRR.day $^{-1}$ or 8.5 USD for no recreational boating. Additionally, the implicit price for $\mathrm{HC} 2$ reflects that a decrease in the number of Hara bundles collected (from 10 to 5 bundles), due to improved protection, has a marginal value of 103924 IRR.hsld ${ }^{-1}$.day ${ }^{-1}$. Coastal communities prefer recreational opportunities, fishing activities and Hara cutting, respectively.

\subsection{Welfare estimate results}

To determine the changes to compensating surplus in response to possible alternative projects, the expression given in equation (7) is evaluated as a means of comparing welfare in a base-case and alternative situations. The base-case situation here is the status Quo option, which contains the possibility of recreational activities by boat, collecting 10 bundles of Hara 
per marine trip, catching an average of $15 \mathrm{~kg}$ of fish per day, and no payment received. Two protection scenario alternatives were used, as described below:

- Scenario 1 (low level conservation scenario): assumed to have moderate impact on Hara ecosystems, recreational activity by boat is forbidden, Hara cutting and fishing amount reduced to 5 bundles.trip ${ }^{-1}$ and $5-15 \mathrm{~kg}_{\text {.day }}{ }^{-1}$, respectively.

- Scenario 2 (high level conservation scenario): assumed to have low impact on Hara ecosystems, recreational activity by boat is forbidden, Hara cutting and fishing amount

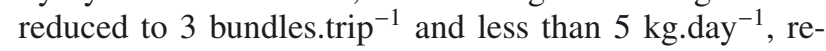
spectively.

The values for welfare change can be interpreted as the amount per day that households are willing-to-accept to lessen their exploitation of Hara forests, rather than accept the status Quo. The daily CS is 570000 IRR.hsld $^{-1}$ and 1457000 IRR.hsld $^{-1}$ for the difference between the sq and scenarios 1 and 2, respectively. This indicates an annual difference of 323755000 IRR.hsld $^{-1}$ (11784 USD) between the values of protection scenarios.

\section{Discussion}

Using the choice modeling approach, the present study was designed to estimate the local benefits that are given up due to the restriction of access to mangrove forests in the Hara Biosphere Reserve. In the case of less Hara exploitation, opportunity costs were represented by the net income foregone by households. We have investigated the heterogeneity of coastal communities' preferences for hypothetical protection options. Provisioning services, such as food and raw materials, are more often valued through direct market pricing methods (de Groot et al., 2012). Many poor communities may depend directly on ecosystems for their subsistence, and a valuation study focusing solely on market prices may fail to capture the importance of such services for local livelihoods. This, in fact, underlines the need to use indicators of importance that are built on quantitative (e.g., ecosystem service flows), spatial (i.e., mapping) and qualitative indicators (e.g., stakeholder perceptions and preferences) (Kenter et al., 2011).

This study showed that if respondents were older, had more children and had a pro-environmental stance, they were more likely to support one of the protection options. A possible explanation might be the fact that older participants always have a low income level, unreliable and unsecure jobs with high physical labor, as well as no alternative source of income. Hence, personal economic gain through compensation payment seems to have been relatively easy and more costeffective for them, and they more often chose one of the protection options with additional payments. Conversely, in rural forest contexts, younger respondents were often engaged in more lucrative and productive activities and hence had a higher opportunity cost associated with restricted access to the Hara forest (Fisher, 2004). They also had less confidence in the hypothetical and risky protection projects. For some respondents, it was important to know how protection was achieved.
Similarly, as the family size increases, subsistence ability decreases, and the likelihood of accepting one of the protection scenarios increases. This is due to families earning more money from the compensation payments than the actual income they earn through fishing and associated activities.

The significant positive relationship that we found between protection and pro-environmental involvement was less surprising because they had already participated in Hara forest protection projects (even though the previous involvement did not entail less restriction for them) and could better relate to the Hara forest protection options, compared to people who considered these forests only as a source of livelihood with direct personal benefits.

Another important finding was that fishermen and high income participants tended to reject protection options more often than non-anglers and low income households, who preferred the status Quo option. This is because higher income households are not only more productive but also have better options for redirecting labor resources and other inputs from Hara forest exploitation to other activities. Thus, compared to individuals with fewer or no alternative options for work, having opportunities to engage in salaried work considerably lowers a person's required compensation. However, these results differ from Liu and Wirtz (2010) findings, which showed that households with less children and higher monthly income are more likely to state that they are willing to pay for protection options to prevent coastal resources from oil pollution. The protection options resulted in not only a direct economic loss for fishermen but also uncertain consequences for rural communities that are dependent on fishing for their subsistence. In fact, fishermen were afraid that the research might lead to more restrictive rules over their access to Hara forest resources and the loss of their jobs. Sometimes it was observed in surveys that respondents were cautious about reporting their actual use of Hara products, not wanting to be considered forest encroachers. This finding is in agreement with Kaffashi et al. (2012), showing that anglers and hunters, who directly depend on wetland resources, did not want to significantly contribute to preserving and improving the wetland's biodiversity because they wanted to secure their access to wetland without restriction and additional payment.

Generally, the majority of people living in or near Hara forest areas derive their principal income from fishing and related activities, and the direct harvest of mangrove wood or leaves is rarely a full-time occupation for them. Curbing access to Hara forests imposes opportunity costs on local people who have traditionally relied on them to obtain resources. Therefore, they should divert labor and inputs to other income generating activities. However, the low educational quality of local people has led to a lack of alternative occupational options for them.

Comparing implicit prices for each attribute in Table 5 showed that respondents prefer recreational opportunities, followed by fishing activities, and lastly Hara cutting. Recreational opportunities represent an alternative potentially valuable and sustainable source of income for many local populations, especially where the forests are easily accessible. Respondents are willing to accept approximately 80545 IRR.day $^{-1}$ less in compensation if the purpose of 
protection is restricting fishing activities as opposed to prohibition of recreational opportunities and 124112 IRR.day $^{-1}$ less if the purpose is lessening Hara cutting. As mentioned above, households have few animals, and the amount of Hara collecting is relatively low. Hara cutting is not a permanent job, and the low compensation connected with it may reflect the low level of household dependency on it. In fact, the lowest level of this attribute may be sufficient for them. It is interesting that the stated WTA is lower than the potentially foregone income from fishing or recreational boating, suggesting that there are other determinants of WTA that seem to be at least as important as foregone income measures. Furthermore, the above hypothetical protection scenarios do not completely exclude human impacts on Hara forests and they maintain access to forest resources as they had before implementation of protection measures.

In this study, we focused on the direct use values of Hara forests for the surrounding poor communities, as well as the need for more research to be performed, because these forests have many non-use benefits. This information is suitable for use by regional planners and managers in determining which Hara forest use options in HBR will provide the greatest benefits to the local community. It will also provide policymakers with prior knowledge and prescription before implementing any policies that relate to equity concerns.

\section{References}

Adamowicz W., Louviere J. and Williams M., 1994. Combining revealed and stated preference methods for valuing environmental amenities. J. Environ. Econ. Manag., 26, 271-292.

Alongi D.M., 2008. Mangrove forests: resilience, protection from tsunamis, and responses to global climate change. Estuar. Coast. Shelf. S., 76, 1-13.

Alpizar F., Carlsson F. and Martinsson P., 2003. Using choice experiments for non-market valuation. Economic Issues - Stoke on Trent., 8, 83-110.

Bakkegaard R., Jacobsen J., and Thorsen B., 2012. Using a hypothetical auction frame to elicit stated compensation needs to avoid deforestation among households in the Brazilian Amazon. Scandinavian Forest Economics, Proceedings of the Biennial Meeting of the Scandinavian Society of Forest Economics, 23-26, issue 44.

Bennett J. and Blamey R., 2001. The Choice Modelling Approach to Environmental Valuation, Edward Elgar, London, 288 p.

Birol E. and Cox V., 2007. Using choice experiments to design wetland management programmes: The case of Severn Estuary Wetland, UK. J. Environ. Plann. Manage., 50, 363-380.

Boxall P.C., Adamowicz W.L., Swait J., Williams M. and Louviere J., 1996. A comparison of stated preference methods for environmental valuation. Ecol. Econ., 18, 243-253.

Braat L.C. and de Groot R., 2012. The ecosystem services agenda: bridging the worlds of natural science and economics, conservation and development, and public and private policy. Ecosyst. Serv., 1, 4-15.

Braden J.B. and Kolstad C.D., 1991. Measuring the demand for environmental quality, Elsevier Science, North-Holland, Co.

Bush G., Hanley N. and Rondeau D., 2011. Comparing opportunity cost measures of forest conservation in Uganda; implications for assessing the distributional impacts of forest management approaches (No. 2011-12), University of Stirling, Division of Economics.
Bush G., Hanley N., Moro M. and Rondeau D., 2013. Measuring the Local Costs of Conservation: A Provision Point Mechanism for Eliciting Willingness to Accept Compensation. Land. Econ., 89, 490-513.

Carlsson F., Frykblom P. and Liljenstolpe C., 2003. Valuing wetland attributes: an application of choice experiments. Ecol. Econ., 47, 95-103.

Casey J.F., Kahn J.R. and Rivas A.A., 2008. Willingness to accept compensation for the environmental risks of oil transport on the Amazon: a choice modeling experiment. Ecol. Econ., 67, 552559.

Christie M., Fazey I., Cooper R., Hyde T. and Kenter J.O., 2012. An evaluation of monetary and non-monetary techniques for assessing the importance of biodiversity and ecosystem services to people in countries with developing economies. Ecol. Econ., 83, 67-78.

Costanza R., de Groot R., Sutton P., van der Ploeg S., Anderson S.J., Kubiszewski I., Farber S. and Turner R.K., 2014. Changes in the global value of ecosystem services. Global Environ. Change., 26, $152-158$.

de Groot R., and Hermans L.M., 2009. Broadening the picture: Negotiating payment schemes for water-related environmental services in the Netherlands. Ecol. Econ., 68, 2760-2767.

de Groot R., Brander L., Van Der Ploeg S., Costanza R., Bernard F., Braat L., Christie M., Crossman N., Ghermandi A. and Hein L., 2012. Global estimates of the value of ecosystems and their services in monetary units. Ecosyst. Serv., 1, 50-61.

FAO (Food and Agriculture Organization of the United Nations), 2007. The world's mangroves 1980-2005. FAO Forestry Paper, Report 153, FAO, Rome.

Fisher M., 2004. Household welfare and forest dependence in Southern Malawi. Environ. Dev. Econ., 9, 135-154.

Gadaud J. and Rambonilaza M., 2010. Amenity values and payment schemes for free recreation services from non-industrial private forest properties: A French case study. J. Forest Econ., 16, 297-311.

Giri C., Ochieng E., Tieszen L.L., Zhu Z., Singh A., Loveland T., Masek J. and Duke N., 2011. Status and distribution of mangrove forests of the world using earth observation satellite data. Global Ecol. Biogeogr., 20, 154-159.

Hall J., Viney R., Haas M. and Louviere J., 2004. Using stated preference discrete choice modeling to evaluate health care programs. J. Bus. Res., 57, 1026-1032.

Kaffashi S., Shamsudjn M., Radam A., Rahjrn K.A., Yacob M., Muda A. and Yazid M., 2011. Economic valuation of Shadegan international wetland, Iran: Notes for conservation. Reg. Environ. Chang., 11, 925-934.

Kenter J.O., Hyde T., Christie M. and Fazey I., 2011. The importance of deliberation in valuing ecosystem services in developing countries - Evidence from the Solomon Islands. Global Environ. Chang., 21, 505-521.

Lancaster K.J., 1966. New Approach to Consumer Theory. J. Polit. Econ., 74, 132-157.

Lee S.Y., Primavera J.H., Dahdouh-Guebas F., McKee K., Bosire J.O., et al., 2014. Ecological role and services of tropical mangrove ecosystems: a reassessment. Global Ecol. Biogeogr., 23, 726-743.

Liu X. and Wirtz K.W., 2010. Managing coastal area resources by stated choice experiments. Estuar. Coast. Shelf. S., 86, 512-517.

MA Millennium Ecosystem Assessment, 2005. Ecosystem and Human Wellbeing: Synthesis, Island Press, Washington DC.

McConnell K.E. and Tseng W.C., 1999. Some preliminary evidence on sampling of alternatives with the random parameters logit. Mar. Resour. Econ., 14, 317-332. 
McFadden D., 1974. Conditional logit analysis of qualitative choice behaviour. In: Zarembka P. (ed.), Frontiers in Econometrics, Academic Press, New York, 105-142.

Mitsch W.J. and Gosselink J.G., 2015. Wetlands, 5th edition, John Wiley \& Sons, Inc., Hoboken, NJ, 744 p.

Neinavaz E., Karami M. and Danehkar A., 2011. Investigation of great egret (Casmerodius albus) breeding success in Hara biosphere reserve of Iran. Environ. Monit. Assess., 179, 301-307.

O'Garra T., 2012. Economic valuation of a traditional fishing ground on the coral coast in Fiji. Ocean. Coast. Manag., 56, 44-55.

Sharzehi G.A. and Jalili P., 2013. Choice Modeling: a new approach to valuation of environmental commodity; case study: ganjnameh, hamedan. Econ. Res., 3, 1-18 (in Persian).
Valiela I., Bowen J.L. and York J.K., 2001. Mangrove forests: one of the world' s threatened major tropical environments. Bioscience, $51,807-815$.

Vo Q.T., Kuenzer C., Vo Q.M., Moder F. and Oppelt N., 2012. Review of valuation methods for mangrove ecosystem services. Ecol. Indic., 23, 431-446.

Walters B.B., Rönnbäck P., Kovacs J.M., Crona B., Hussain S.A., Badola R., Primavera J.H., Barbier E. and Dahdouh-Guebas F., 2008. Ethnobiology, socio-economics and management of mangrove forests: a review. Aquat. Bot., 89, 220-236.

Zahed M.A., Rouhani F., Mohajeri S., Bateni F. and Mohajeri L., 2010. An overview of Iranian mangrove ecosystems, northern part of the Persian Gulf and Oman Sea. Act. Ecol. Sin., 30, $240-244$.

Cite this article as: Z. Mashayekhi, A. Danehkar, G.A. Sharzehi, V. Majed, 2016. Coastal Communities WTA Compensation for conservation of mangrove forests: a choice experiment approach. Knowl. Manag. Aquat. Ecosyst., 417, 20. 